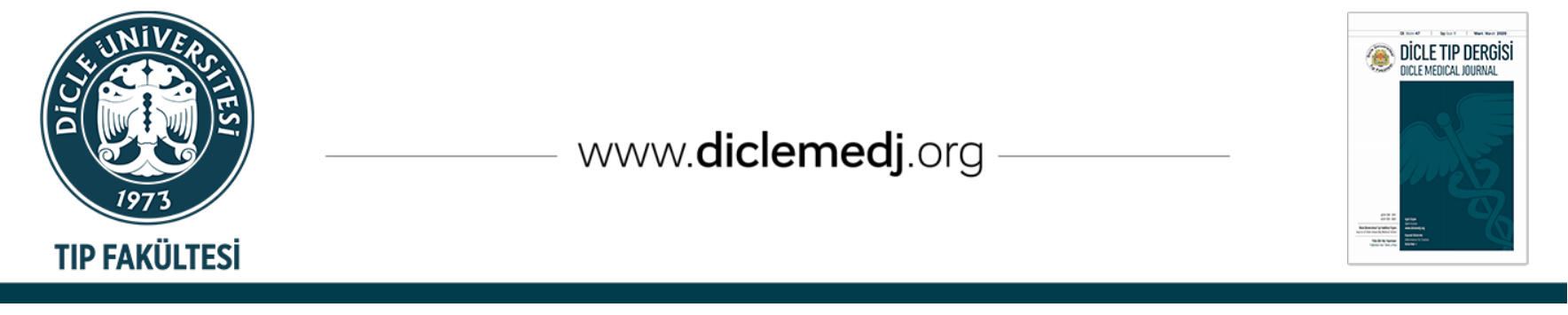

Original Article / Özgün Araştırma

\title{
Evaluation of Nosocomial Infections in Reanimation Intensive Care Unit: Analysis of Six Years Surveillance
}

\author{
Berna Kaya Ugur iD 1 , Ayse Ozlem Mete ${ }^{\text {D }} 2$ \\ 1 Gaziantep University Faculty of Medicine, Department of Anesthesiology and Reanimation Gaziantep, Turkey \\ 2 Gaziantep University Faculty of Medicine, Department of Infectious Diseases and Clinical Microbiology, Gaziantep, Turkey \\ Received: 08.11.2019; Revised: 21.07.2020; Accepted: 22.07.2020
}

\begin{abstract}
Objective: Nosocomial infections (NI) raise costs due to the increased in mortality and long-term hospitalization. There are more NIs in intensive care units (ICU) probably due to invasive procedures. In order to reduce NIs, the most important step in terms of prevention is the identification of the common pathogens with their infection rates among these units. For this purpose, the centers should conduct surveillance studies and often evaluate their data.

Methods: We evaluated the infection rates and ratios, between January 1st, 2014 and August 31st, 2019 in Reanimation Intensive Care Unit (ICU) in our hospital. Method of the surveillance was, prospective, active, laboratory and patient based.

Results: In our reanimation ICU, 1591 patients were followed up during the study period. 192 NIs were observed in 179 patients on 21,840 intensive care days. NI rate was found to be 11.25 and Infection density rate was found to be 8.20 and their change over the years was examined. Analysis regarding the source of infections revealed that ventilator-related pneumonia $(27.08 \%)$ and central venous catheter-related blood-stream infection $(25.52 \%)$ was most commonly observed during the study period. The ventilator usage rate was 0.54 (11.859 ventilator days) and the central venous catheter usage rate was 0.94 (20.566 catheter days) in the study period. Acinetobacter baumannii $(n=96,50 \%)$, Pseudomonas aeruginosa $(n=24,12.5 \%)$ and Klebsiella pneumonia $(n=18,9.38 \%)$ were most commonly isolated.
\end{abstract}

Keywords: Nosocomial Infections; Invasive Device Associated Infections; Ventilator Associated Event.

DOI: 10.5798/dicletip.799633

Correspondence / Yazışma Adresi: Ayse Ozlem Mete, Gaziantep University, Faculty of Medicine, Department of Infectious Diseases and Clinical Microbiology, Gaziantep/Turkey e-mail: ayseozlem_ornek@hotmail.com 


\section{Reanimasyon Yoğun Bakım Ünitesinde Gelişen Nozokomiyal Infeksiyonların Değerlendirilmesi: Altı Yıllık Sürveyans Verilerinin Analizi}

Öz

Amaç: Nozokomiyal enfeksiyonlar (NE) artmış mortalite ve uzayan yatışlar sonucu maliyet artışına sebep olurlar. Özellikle uygulanan invaziv girişimlere bağlı olarak oranlar yoğun bakım ünitelerinde (YBÜ) daha yüksektir. NE'leri azaltabilmek için merkezlerin daha ötesi ünitelerin kendi enfeksiyon oranlarını izlemesi sık görülen patojenleri bilmesi yapılacak önleme faaliyetleri açısından en önemli basamaktır. Bu amaçla merkezler sürveyans çalışmaları yürütüp verilerini düzenli olarak değerlendirirler.

Yöntemler: Bu çalışmada 1 Ocak 2014 - 31 Ağustos 2019 tarihleri arasında hastanemiz Reanimasyon YBÜ'nün enfeksiyon hızları ve oranları değerlendirilmiştir. Çalışma, laboratuar ve hasta temelli olarak yürütülen aktif sürveyans verileri prospektif olarak incelenmiştir.

Bulgular: Sonuç olarak çalışma döneminde reanimasyon yoğun bakım ünitemizde 1591 hasta takip edilmiştir, 21.840 yoğun bakım gününde 179 hastada $192 \mathrm{NE}$ atağı izlenmiştir. NE hızı:11,25; Enfeksiyon dansite hızı: 8.20 olarak bulunmuş ve yıllara gore değişimi incelenmiștir. Tüm çalışma boyunca İnvaziv alet ilişkili enfeksiyon oranları değerlendirildiğinde, \%27,08'i ventilator ilișkili pnömoni, \%25,52'si santral venöz kateter enfeksiyonu olarak bulundu. Çalışma döneminde ünitedeki ventilator kullanım hızı:0,54 (11.859 ventilatör günü) ve santral venöz kateter kullanım oranı: 0,94 (20.566 kateter günü) olarak hesaplanmıştır. En sık olarak üreyen etken yıllara göre değişmekle birlikte toplamda Acinetobacter baumannii (n=96, \%50), Pseudomonas aeruginosa $(n=24, \% 12,5)$, Klebsiella pneumonia $(n=18, \% 9,38)$, Candida spp. ( $\mathrm{n}=20,10,4 \%)$ izole edilmiştir.

Anahtar kelimeler: Nozokomiyal Enfeksiyonlar, İnvaziv Alet İlişkili İnfeksiyonlar, Ventilatör İlişkili Olay.

\section{INTRODUCTION}

Nosocomial infections (NIs) are still a leading problem in Intensive Care Units (ICUs) when higher morbidity, mortality, increased duration of hospital stay, and hospital charges are considered $^{1}$. Although the patient population at other clinics is larger than the intensive care units, the rate of NIs is higher in ICUs owing to various invasive interventions like mechanical ventilation and catheterization, use of wide-spectrum antibiotics and existence of comorbities ${ }^{2-4}$.

The leading part of infection control program is the surveillance of NIs. Of course, the best approach for the management of infection is prevention infections from happening.

Detection of relevant microorganism surveillance and their resistance to antimicrobial patterns in ICUs with the awareness of healthcare professionals and interdisciplinary collaboration help building successful infection control measures ${ }^{5,6}$. Efforts given to infection control modalities with surveillance activities of individual institutes improve the quality of health care and lessen hospital costs.

The aim of this study is to evaluate NIs, the sites of these infections, the frequency and distribution of agent microorganisms, infection rates associated with invasive procedures at a tertiary reanimation ICU in a 6 year period.

\section{METHODS}

The infection rates and ratios, between January 1st, 2014 and August 31st, 2019 in the Reanimation ICU in our hospital were evaluated. Gaziantep University Hospital is tertiary referrals center with a capacity of nearly 1000 beds the southeast region of Turkey. The reanimation ICU is also a tertiary ICU with 14 beds. The method of surveillance is active, prospective, laboratory, and patient-based. The data we obtained for this study is based on the data that we collected by active surveillance for Nis. Hospital infection control team performed the surveillance, using the criteria proposed by the Centers for Diseases Control and Prevention (CDC) and National Nosocomial Infections Surveillance System 
(NNIS) methodology, every term and definition related to NI was made according to this guide ${ }^{7-9}$. This team consists of an infection control physician and two nurses, that regularly (visit) every unit in the hospital thrice a week. All the patients hospitalized to the unit during the study period, above 18 years of age included in the study. A standard form of data collection was used to record all of the cases suffering from NI. This form was consisted of the patient data including the patients' age, gender, risk factors for NIs, accompanying comorbidities, any interventions performed in hospital, cause for hospitalization, and the profile of treatment. Medical reports were reviewed to detect the patients who had signs and symptoms of infection from archives, in terms of medical and nursing records, reports of microbiologic analysis, patient temperatures and records of antibiotic treatment and nursing notes. The infection control team filled in the standard worksheet for each patient. Classification of NIs were consisted of the genitourinary infections, pneumonia, ventilator-associated event, bloodstream infections (BSIs), catheter related BSI, and other (infections of gastrointestinal and central nervous system or infections of surgical site, eye, prosthesis infections or catheter-related local infections).

The definition of ventilator-associated pneumonia (VAP) was 'persistent pulmonary infiltrates on chest radiographs combined with purulent tracheal secretions and/or body temperature greater than or equal to $38.5^{\circ} \mathrm{C}$ or less than or equal to $36.5^{\circ} \mathrm{C}$ and/or peripheral blood leukocyte count greater than or equal to $10 \times 109$ /L or less than or equal to $4 \times 109 / \mathrm{L}^{6}$.

A definite diagnosis of VAP required microbiological confirmation by quantitative culture from a protected specimen brush $(>103$ $\mathrm{CFU} / \mathrm{mL}$ ), plugged telescopic catheter specimen (>103 CFU/mL), bronchoalveolar lavage (BAL) fluid specimen $(>104 \mathrm{CFU} / \mathrm{mL})$, or endotracheal aspirate $(>105 \mathrm{CFU} / \mathrm{mL})^{10}$.

The data collection of nosocomial microorganisms was performed on a daily basis from Hospital Core Laboratory and Infection Diseases Department Laboratory. For blood culture analysis, The
BacT/ALERT® 3D Microbial Detection System (bioMerieux/France) was used. The disk diffusion method according to the criteria of The Clinical and Laboratory Standards Institute (CLSI) ${ }^{11}$ was used to determine the antibiotic susceptibilities.

The infection rate was calculated using the formula: (number of nosocomial infection/number of the patient) $x$ 100, calculation of the incidence density of NIs was performed using the formula: (nosocomial infection/days of patient stay) x 1000 while the medical device-related infection rate was calculated using the formula: (number of episodes/number of days the medical device was used) x 1000 .

Ethics committee approval was received from our university Faculty of Medicine (2019/356).

\section{RESULTS}

A total of 1591 patients were included in the content of the study who were hospitalized at the ICU during the study period. Nosocomial infections were observed in 179 patients among 21.840 ICU days. Data regarding date and density are shown in Table I. A total of 192 microorganisms were isolated from the 179nosocomial infection cases. The most to least common isolated pathogens were Acinetobacter baumannii (n=96, 50\%), Pseudomonas aeruginosa $(n=24,12.5 \%)$, Klebsiella pneumoniae $(\mathrm{n}=18,9.38 \%)$, Candida species $(\mathrm{n}=20,10.41 \%)$. Distribution of the causative microorganisms across the study period is shown in Table II. Analysis regarding the source of infections revealed that ventilator-related pneumonia $(27.08 \%)$ and central venous catheter-related blood-stream infection (25.52\%) was most commonly observed all along the study period. Between the study period, an increase in rate and density of nosocomial infections were observed from 2014 and beyond as well as isolation rates and density rates. Infections with respect to source in 2014 revealed that they were most commonly associated with invasive procedures such as ventilator-related pneumonia/ventilatorassociated event $(46.87 \%)$ and central venous catheter-related blood-stream infection 
Kaya Ugur B. , Mete A. O.

(34.37\%). Rate, ratio, and numbers of invasive procedures, which are related to these infections, according to years of the study period are shown in Table III.

Table I: Rate of incidence and densities of NIs according to the years

\begin{tabular}{|l|l|l|l|l|l|}
\hline $\begin{array}{l}\text { Rates } \\
\text { Years }\end{array}$ & $\begin{array}{l}\text { Patients } \\
\text { (n) }\end{array}$ & $\begin{array}{l}\text { Patient } \\
\text { Day }\end{array}$ & $\begin{array}{l}\text { Infections } \\
\text { (n) }\end{array}$ & $\begin{array}{l}\text { Infection } \\
\text { rate }\end{array}$ & $\begin{array}{l}\text { Infection } \\
\text { density }\end{array}$ \\
\hline $\mathbf{2 0 1 4}$ & 242 & 3012 & 59 & 24.38 & 19.59 \\
\hline $\mathbf{2 0 1 5}$ & 253 & 3491 & 28 & 11.07 & 8.02 \\
\hline $\mathbf{2 0 1 6}$ & 279 & 3558 & 28 & 10.4 & 7.87 \\
\hline $\mathbf{2 0 1 7}$ & 356 & 4647 & 29 & 8.15 & 6.24 \\
\hline $\mathbf{2 0 1 8}$ & 306 & 4525 & 19 & 6.21 & 4.20 \\
\hline $\mathbf{2 0 1 9} *$ & 155 & 2607 & 16 & 10.32 & 6.14 \\
\hline Total & $\mathbf{1 5 9 1}$ & $\mathbf{2 1 8 4 0}$ & $\mathbf{1 7 9}$ & $\mathbf{1 1 . 2 5}$ & $\mathbf{8 . 2 0}$ \\
\hline
\end{tabular}

*The first 8 months of year 2019.
Table II: The distribution of microorganisms of Nis(NIs) for years

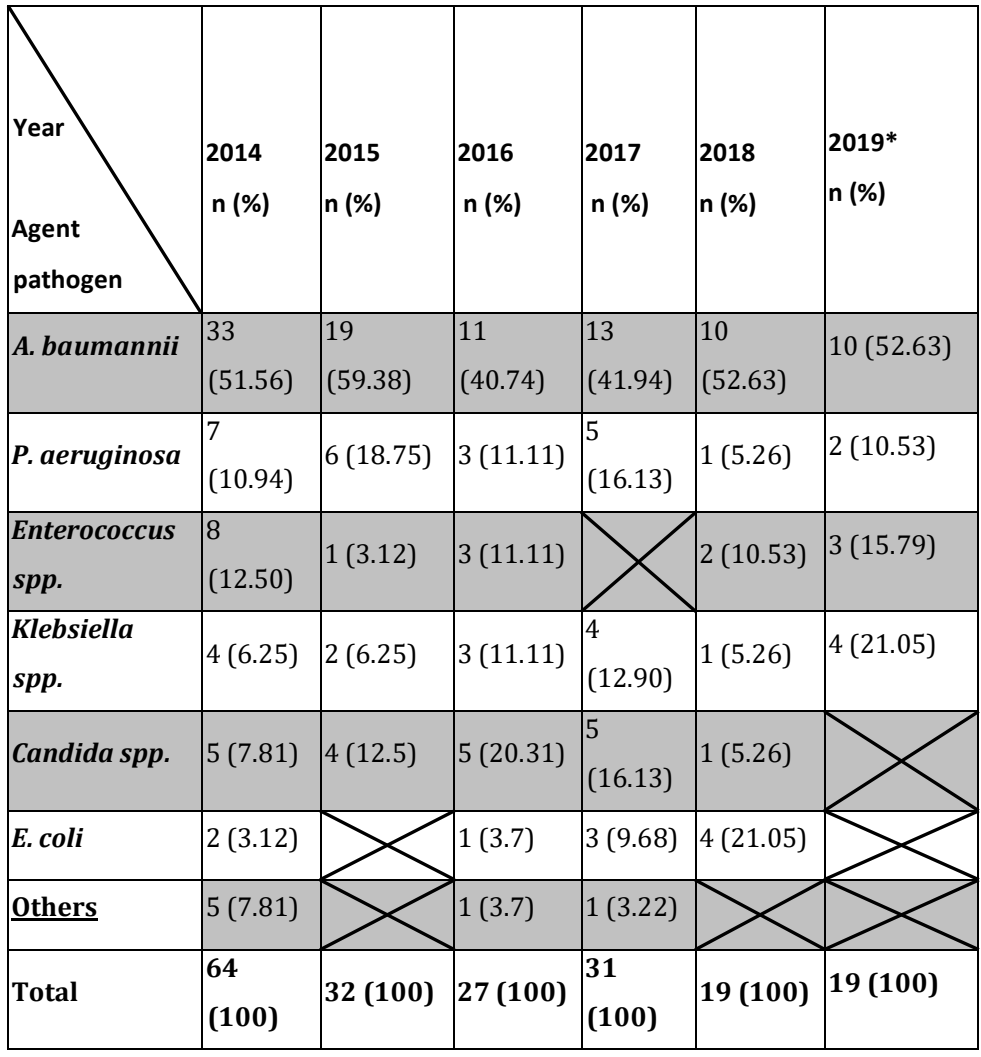

${ }^{*}$ The first 8 months of year 2019

Table III: Distribution of invasive device-associated infection rates and utilization ratios according to years

\begin{tabular}{|l|l|l|l|l|l|l|l|l|l|l|l|l|}
\hline Year & $\begin{array}{l}\text { Patient } \\
\text { number }\end{array}$ & $\begin{array}{l}\text { Patient } \\
\text { day }\end{array}$ & Vent. day & VAP & VUR & $\begin{array}{l}\text { VAP } \\
\text { Rate }\end{array}$ & VAE & VAE rate & CVC day & $\begin{array}{l}\text { CA- } \\
\text { BSI }\end{array}$ & CVCUR & $\begin{array}{l}\text { CA-BSI } \\
\text { rate }\end{array}$ \\
\hline $\mathbf{2 0 1 4}$ & 242 & 3012 & 1520 & 1 & 0,5 & 0,66 & 29 & 19,08 & 2842 & 23 & 0,94 & 8,09 \\
\hline $\mathbf{2 0 1 5}$ & 253 & 3491 & 1899 & 0 & 0,54 & 0 & 13 & 6,85 & 3299 & 11 & 0,95 & 3,33 \\
\hline $\mathbf{2 0 1 6}$ & 279 & 3558 & 2210 & 3 & 0,62 & 1,36 & 8 & 3,62 & 3354 & 9 & 0,94 & 2,68 \\
\hline $\mathbf{2 0 1 7}$ & 356 & 4647 & 2466 & 3 & 0,53 & 1,22 & 12 & 4,87 & 4339 & 8 & 0,93 & 1,84 \\
\hline $\mathbf{2 0 1 8}$ & 306 & 4525 & 2447 & 0 & 0,54 & 0 & 6 & 2,45 & 4297 & 7 & 0,95 & 1,63 \\
\hline $\mathbf{2 0 1 9} *$ & 155 & 2607 & 1317 & 0 & 0,51 & 0 & 10 & 7,59 & 2435 & 4 & 0,93 & 1,64 \\
\hline Total & $\mathbf{1 5 9 1}$ & $\mathbf{2 1 8 4 0}$ & $\mathbf{1 1 8 5 9}$ & $\mathbf{7}$ & $\mathbf{0 , 5 4}$ & $\mathbf{0 , 5 9}$ & $\mathbf{7 8}$ & $\mathbf{6 , 5 8}$ & $\mathbf{2 0 5 6 6}$ & $\mathbf{6 2}$ & $\mathbf{0 , 9 4}$ & $\mathbf{3 , 0 1}$ \\
\hline
\end{tabular}

VUR: Ventilator utilization rate; VAE: ventilatory associated event; CVCUR: Central catheter utilization rate; VAP: Ventilator associated pneumonia; BSI: Blood stream infection

*First 8 months of the year 2019. 


\section{DISCUSSION}

NIs result in increased mortality and treatment costs by causing prolonged hospitalization ${ }^{12,13}$. Prolonged stay at the ICU, invasive procedures, and extensive use of broad-spectrum antibiotics are the most important risk factors associated with the development of $\mathrm{NI}^{14}$. High mortality rates associated with NI seen in ICU emphasize the importance of these infections. There are more cross-infection, contaminations, and common use of broad-spectrum antibiotics at the ICU when compared with other units of hospitals. Therefore, NIs are seen in these units 5-10 times more frequently than other units ${ }^{15}$. In 17 European countries (EPIC), a study of 10,038 patients in 1417 adult ICUs reported that NI was observed in $20.6 \%$ of patients once or more ${ }^{14}$. In another paper regarding 56 ICUs from 22 tertiary hospitals in Turkey, it was found that $49 \%$ of ICU patients developed NIs once or more ${ }^{16}$.

In our study, although the rate and density of NI vary over the years, the average rate was found to be ${ }^{10,32}$ and density ${ }^{6,14}$. In different studies conducted in Turkey, the rate of NI in ICUs was reported to be between 5.3 and $64.6 \%{ }^{17,18}$. Increases in the number of NI can be attributed to the increased survival of patients with severe co-morbidities and increased risk of NI during this period due to the increase in medical technology and ICU experience, as well as disruption of infection control practices due to increased number of patients and increased workload. The most important finding of our study is the significant increase in the rate of $\mathrm{NI}$ in 2014 compared to other years. The reasons for not continuing the same rates in 2015 may be due to 1) switching to closed system tracheal aspiration in 2015,2) an increase in the number of nursing staff and nurses in this period, 3) increasing the frequency of training of staff, 4) frequent hand hygiene controls.

The antibiotic susceptibility and diversity of microorganisms have significantly changed due to variations in ICU inpatient profiles and treatment options in recent years ${ }^{19}$. Gramnegative bacilli were at the forefront among the pathogenic microorganisms in the 1960s and 1970s, while the widespread use of broadspectrum cephalosporins in these years resulted in an increase in infections with grampositive microorganisms.

However, the results of the EPIC study revealed that gram-negative and gram-positive agents were equally effective (30\% in Staphylococcus aureus, 29\% in Pseudomonas aeruginosa) in ICU ${ }^{14}$. In the studies carried out in Turkey the most common isolated pathogenic microorganisms in ICU were known as; Staphylococcus aureus (19-37\%) and Pseudomonas aeruginosa (17-32\%), Acinetobacter baumannii has been reported as the most common bacteria throughout the studies for the last 10 years ${ }^{18,20}$. Irrational use of antibiotics, unnecessary long-term prophylaxis, no reduction of the antibiotics due to culture results, and failure to comply with infection control measures when necessary may be among the reasons. In our study, as the other studies in our country, A. baumannii was the most frequently isolated microorganism in all study periods, although other causative pathogens varied over the years.

Most of the infections occur in ICUs and invasive device-associated infections (IDAIs) are the utmost risk factors. Therefore, targeted surveillance and calculation of rates per 1000 device-days, is generally in use in medical centers of many western countries and is suitable to make comparisons between similar centers $^{4,5}$. Mechanical ventilation and endotracheal intubation are the leading risk factors for the development of nosocomial pneumonia (NP), therefore a significant proportion of NPs are constituted by VAP. In EPIC study $46 \%$ of infections due to intensive care were reported to be pneumonia. In our study, the frequency and rate of infection development in cases where invasive devices were used were calculated as CA-BSI: 3.01 and 
VAP rate: 0.59 . The velocity of our unit is very low compared to the VAP rates (38.7-49.5\%) found in many previous studies ${ }^{21-23}$. Probably, the reason for this is that these papers were written before 2012-2013 and not calculated according to the new VAP criteria ${ }^{7}$.

The diagnosis of VAP results in a prolonged hospital stay about 14-days and also costs around an additional amount of $\$ 41,000^{24}$.

VAP definition was mentioned previously but this description is too inclusive and results in more "new" VAP diagnoses ${ }^{10,25}$. The last radiographic signs were correlated with autopsy results and a study by Wunderink et al and air bronchogram was reported as the most accurate radiographic finding with a diagnostic accuracy of $64 \%{ }^{26}$. Therefore, in 2013, CDC modified from VAP to Ventilator-Associated Event (VAE) surveillance in order to define a more objective surveillance criteria9. A wider variety of situations are identified by VAE surveillance and events are classified into three categories: ventilator-associated conditions (VAC), infection-related ventilator-associated complications (IVAC), and possible/probable VAP. In order to provide clearer and more global communication, the infection control committee maintains its records in 2014 by distinguishing between VAP and VAE according to CDC criteria, and thus, it is possible to distinguish some non-ventilator conditions more clearly than VAP ${ }^{27}$.

Clinical findings and symptoms are similarly undependable for surveillance purposes. The diagnosis of pneumonia (presence of a radiographic opacity and clinical features such as fever, leukocytosis, and purulent sputum) was made with a sensitivity and specificity ranging between $69 \%$ and $75 \%{ }^{28}$. There is considerable debate regarding microbiological evidence depending mostly on difficulties to differentiate between colonization and infection. Among ICU patients colonization within 24 hours was revealed in $22 \%$ of 95 patients in the influential papers published by Johanson and colleagues ${ }^{29}$.

The novel definition of VAE aimed to uphold surveillance in a steady approach at all medical centers. The emphasis in mechanically ventilated patients is put on various sets of conditions with worsening respiratory status instead of lung infection. The effect of VAP prevention bundles is not certain because definitions of VAC and IVAC are not primarily intended to be used clinically.

Another invasive device-related infection detected in our study was CLABSI. Although the frequency varies according to years, the rate was higher in 2014 than other infections. However, when examined in general or on dates, the CLABSI ratio (3.01 / 1000) we found in our study was lower than the results of many studies conducted in Turkey and abroad (18.9$29 \%)^{26,27}$. In a study conducted in our own intensive care units, ICU rates for 2011 were higher compared to 2014 and beyond ${ }^{30}$. In another study that was also conducted in our hospital, CLABSI rates were found to be 8.3$15.8 \%$ in $2007-2009^{31}$.

\section{CONCLUSION}

Infection control modalities with surveillance activities of individual institutes improve the quality of health care and lessen hospital costs. To evaluate the sites of these infections, infection factors, and infection rates associated with invasive procedures, is important for clinics to take their own data and to reduce these parameters.

Ethics Committee Approval: Ethics committee approval was received from our university Faculty of Medicine (2019/356).

Declaration of Conflicting Interests: The authors declare that they have no conflict of interest.

Financial Disclosure: No financial support was received. 


\section{REFERENCES}

1. Sheng WH, Wang JT, Lin MS, et al. Risk factors affecting inhospital mortality in patients with nosocomial infections. J Formos Med Assoc. 2007; 106: $110-8$

2. Akalın H. Infections in intensive care units: risk factors and epidemiology. Turk J Hosp Infect. 2001; 5: $5-16$

3. Eggiman P, Pillet D - Infection control in the ICU. Chest Journal, 2001; 120: 2059-93.

4. Çağatay Atahan A, Özsüt H. Infections and antimicrobial therapy in intensive care unit. Yoğun Bakım Dergisi. 2001; 1: 21-32.

5. Khan HA, Baig FK, Mehboob R. Nosocomial infections: epidemiology, prevention, control and surveillance. Asian Pac J Trop Biomed. 2017; 7: 47882.

6. Celen MK, Tamam Y, Hosoglu S, et al.Multiresistant bacterial colonization due to increased nurse workload in a neurology intensive care unit. Neurosciences. 2006; 11: 265-70.

7. CDC, Guidelines \& Guidance Library https://www.cdc.gov/infectioncontrol/guidelines/ index.html (accessed on 10th September 2019).

8. Guidelines for the Prevention of Intravascular Catheter-Related Infections (2011) https://www.cdc.gov/infectioncontrol/pdf/guideli nes/bsi-guidelines-H.pdf

9. National Healthcare Safety Network. Deviceassociated module ventilator-associated event (VAE); Centers for Disease Control and Prevention website.

2017.

http://www.cdc.gov/nhsn/pdfs/pscManual/10-

VAE_FINAL.pdf (accessed on 10th September 2019).

10. M. Nguile-Makao, R. Zahar, A. Français, et al. Attributable mortality of ventilator-associated pneumonia: respective impact of main characteristics at ICU admission and VAP onset using conditional logistic regression and multi-state models. Intensive care medicine, 2010; 36: 781-9.

11. Clinical Laboratory Standards Institute. Performance standards for antimicrobial susceptibility testing. Twenty-third Informational Supplement. M100-S23, CLSI Vol 34, No:1, 2014. Wayne, PA (accessed on 10th September 2019).
12. Garner JS, Jarvis WR, Emori TG, et al. CDC definitions for nosocomial infections, 1988. Am J Infect Control. 1988;16: 128-40.

13. Bueno-Cavanillas $\mathrm{A}$, Delgado-Rodriguez $\mathrm{M}$, Lopez-Luque A, et al. Influence of nosocomial infection on mortality rate in an intensive care unit. Crit Care Med. 1994; 22: 55-60.

14. Vincent JL, Bihari DJ, Suter PM, et al. The prevalence of nosocomial infection in intensive care units in Europe. Results of the European Prevalence of Infection in Intensive Care (EPIC) Study. EPIC International Advisory Committee. JAMA. 1995; 274: 639-44.

15. Saba R. Supportive measures in ICU patients: which patients have to be isolated? J Intens Care 2002; 2 : 133-8.

16. Esen S, Leblebicioglu $H$. Prevalence of nosocomial infec $\neg$ tions at intensive care units in Turkey: a multicentre 1-day point prevalence study. Scand J Infect Dis. 2004; 36: 144-8.

17. Tekeli E. ICU infections of yesterday, today and tomorrow. J Intens Care. 2002; 2: 9-13.

18. T. Adnan, T. Recep, D. Tuba, et al. Evaluation of hospital infections developing in intensive care unit during a decade and review of literatüre. Dicle medi j. 2012; 39: 492-8

19. F. G. Mehmet, H. Salih, A. Celal, et al. Surveillance of Nosocomial Infections in Dicle University Hospital: A Ten-Year Experience. Turk J Med Sci. 2008; 38: 587-93.

20. D. Necla, O. Esra, D. Semih, et al. Three-year evaluation of nosocomial infection rates of the ICU. Rev. Bras. Anestesiol. 2013; 63: 73-84.

21. İnan D, Saba R, Yalcin AN, et al. Device-associated nosocomial infection rates in Turkish medicalsurgical intensive care units. Infect Control Hosp Epidemiol. 2006; 27: 343-8.

22. C. Aslıhan, K. Behice, K. Filiz, et al. Invasive Device-Associated Nosocomial İnfections of $\mathrm{A}$ Teaching Hospital in Turkey; Four Years' Experience. Turk J Med Sci. 2011; 41: 137-47.

23. Rosenthal VD, Maki DG, Salomao R, et al. Deviceassociated nosocomial infections in 55 intensive care units of 8 developing countries. Ann Intern Med. 2006; 145: 582-91. 
24. Z. Eyal, H. Daniel, T. Orly, et al. Health CareAssociated Infections A Meta-analysis of Costs and Financial Impact on the US Health Care System. JAMA Intern Med. 2013; 173: 2039-46.

25. Raoof S and Baumann MH. Ventilator-Associated Events: The New Definition. Am J Crit Care. 2014; 23 : 7-9.

26. Wunderink RG, Woldenberg LS, Zeiss J, et al. The radiologic diagnosis of autopsy-proven ventilatorassociated pneumonia. Chest. 1992; 101: 458-63.

27. G. Raeley, V. Jarin, C.B. Jorge, et al. Risk Factors for Ventilator-Associated Events in a PICU. Pediatric Critical Care Medicine. 2018; 19: 7-13.

28. Fàbregas N, Ewig S, Torres A, et al. Clinical diagnosis of ventilator associated pneumonia revisited: comparative validation using immediate post-mortem lung biopsies. Thorax. 1999; 54: 86773.
29. Johanson WG Jr, Pierce AK, Sanford JP, et al. Nosocomial respiratory infections with gramnegative bacilli: the significance of colonization of the respiratory tract. Ann Intern Med. 1972; 77: 7016.

30. Süner A, Karaoğlan İ, Mete AO, et al. Assessement of bloodstream infections and risk factors in an intensive care unit. Turk J Med Sci. 2015; 45: 124350.

31. C.. Saliha, B. Vuslat, N. Mustafa, et al. Invasive device-associated hospital infection rates, etiological agents, and their antibiotic susceptibilities in the medical intensive care unit of a university hospital in Turkey. Turk J Med Sci. 2013; 43: 33-8. 